\title{
OVERCOMING PARADOX FOR SOCIAL ENTERPRISE DEFINITION: CASE OF LITHUANIA
}

\author{
Laima Okuneviciute Neverauskiene $\mathrm{e}^{1, \mathrm{a}^{*}}$ and Irena Pranskeviciute ${ }^{2, \mathrm{~b}}$ \\ ${ }^{1}$ Lithuanian Social Research Centre, Vilnius Gediminas Technical University, A. Gostauto 9, LT- \\ 01108, Vilnius, Lithuania \\ ${ }^{2}$ Lithuanian Social Research Centre, A.Gostauto 9, LT-01108, Vilnius, Lithuania \\ a'Laima.Okuneviciute@dsti.lt, ${ }^{\mathrm{b}}$ Iren.Pranskeviciute@gmail.com \\ *Corresponding author
}

Cite as: Okuneviciute Neverauskiene, L. Pranskeviciute, I. (2018). Overcoming paradox for social enterprise definition: Case of Lithuania, Ekonomicko-manazerske spektrum, 12(1), 104-118.

Available at: dx.doi.org/10.26552/ems.2018.1.104-118

\begin{abstract}
The study explores dilemma around de jure adopted social enterprise conception and social enterprise universe de facto developing through bottom-up initiatives. The presented analysis of Lithuania case presents sitaution, where conception on social enterprise was adopted following EU framing, and good practices of countries, having strong historicall roots of social enterprise development, but bypassed evaluation of local context. The study shows, that narrow definition of social enterprises, applied to the legal framework of the state leads to deterioration of the social entrepreneurship concept and forms alternative area of various social enterprise models embedding global practices and broad definition of social enterprise. In Lithuania two contradictory domains of de jure and de facto social enterprises emerge and create dichotomous situation where some social enterprise forms are permanently supported and recognized by the state and others - not. Situation of Lithuania is especially referring to Central and Eastern Europe countries where natural development of social enterprises was historically interferred. The study elaborates hypothesis, that adoption of social enterprise conception to national legal framework shall be designed primarily corresponding to de-facto existing social enterprise universe and placing them along a continuum. It shows the need to pay attention to local and global evolutionary discourse and appreciate cross sectoral nature of social enterprises and their special place in the overall economy. It reveals that social entrepreneurship as main catalyst for social innovations go beyond conventional "bi-polar" representations of the economic landscape. The non-profit sector can no longer be viewed as separate to the business or state sector, instead, social enterprise models appear as intermediate actors. This view emphasizes the need for synergetic mixes of resources, cross-sectoral policies making and support means to social enterprise organizations, rather than clear-cut frontiers and divisions between sectors.
\end{abstract}

Keywords: Social Enterprise, non-governmental organization, rural community, public services, decentralisations

JEL Classification: D21, H23, J21, O15, D62, P43 


\section{Introduction}

Gualera \& Borzaga (2009) state that different historical context frames different nature and variety of social enterprise models prevailing in the country or region. Such variety leads to contradictions when states, that do not have historically developed ecosystem for social enterprises. Staicu (2017), urges to apply general social enterprise principles, developed by EMES European Research Network (2011) or presented in Social Business initiative, to legal framing of social enterprise conception on the national level, in accordance with Borzaga \& Defourny (2001), and Defourny (2004). The concept of social enterprise defined by EMES does not seek to supplant existing national concepts. Rather, it is intended to facilitate discourse and discovery of various social enterprise dynamics and developmental trends, argued by Gualera \& Borzaga (2009), and Defourny, Hulgard \& Pestof (2014). The Case of Lithuania presents situation where conception on social enterprise was adopted following EU framing, and good practices of countries, having strong historical roots of social enterprise development, but bypassed evaluation of local context. Situation in Lithuania presents lesson to learn for other countries, where legal framing and de jure conception of social enterprise poorly integrate de facto community of social enterprises, therefore top-down acceleration initiatives do not overlap with bottom up nature and development of social enterprises. Case of Lithuania is especially referring to Central and Eastern Europe countries where natural development of social enterprises was historically interfered.

The paper is an analytic review, building on analysis of scientific literature, research studies and legal framework related to the themes of social innovation, social enterprise concept, social enterprise model. The goal of the study - to explore dilemma around social enterprise conception, de jure adopted in the top-down manner and de facto social enterprise universe developing through bottom-up initiatives. The study elaborates hypothesis, that adoption of social enterprise conception to national legal framework shall be designed primarily corresponding to de-facto existing social enterprise universe and placing them along a continuum from purely social to purely economic, with elements of both to be found at the extremes, according to Gualera \& Borzaga (2009).

The study shows, that narrow definition of social enterprises, applied to the legal framework of the state leads to deterioration of the social entrepreneurship concept and forms alternative area of various social enterprise models embedding global practices and broad definition of social enterprise. The case of Lithuania shows, that two contradictory domains of de jure and de facto social enterprises emerge and create dichotomous situation where some social enterprise forms are permanently supported and recognized by the state and others not. Society, policy makers', donors, supporters and practitioners understanding about social enterprises moves toward polarities, what on one hand encourages rethinking and design of more inclusive definition, on the other - leads to stagnation of public policies and strategies for social enterprise development.

\section{Methodology}

\subsection{Concept and definitions and legal forms of social enterprises in Europe}

Social enterprises emerged to global policy agenda, as well Central and Eastern Europe, on the threshold of centuries, stimulated by the context of complex social and ecological problems, growing unemployment, stagnation of economic growth, followed by rising civil activism and public debates on sustainable business, in accordance with Staicu (2017), O’Byrne et. al (2015), and Bassi et. al (2016). Social enterprises are identified as change 
actors bringing to life social innovations - new solutions to complex public problems, although developing new narratives to policy makers, new models of collaboration around public services and transforming traditional approach to welfare management, De Vries (2015), and Cels et al. (2012) stated. Variety of innovative solutions originated outside conceptual, legal and policy frameworks, they are reflected in diversity of social enterprise models, embracing "a broad range of activities and initiatives that fall along a continuum, including more generally speaking non-conventional entrepreneurial initiatives", according to Gualera \& Borzaga (2009).

The historical roots and nature of social enterprise legal forms and socio-economic models vary through countries and historical periods. Chell (2007), Foster \& Bradach (2005) identify development of Social entrepreneurship as transformational movements of non-profit organizations toward higher financial independence from state subsidies or charity. Austrian Institute for SME Research (2007), and Urich (2013) outline opposite perspective, that social economy was born with the industrial society, when new social needs had to be fulfilled and society modified its values. Bassi, Ecchia \& Guerra (2016) explain polarities by noting, that social enterprise concept had several historical shifts: one from social toward neo-liberal economic at the end of twentieth century and currently is moving through new transition: "Nowadays we are facing a transition period nevertheless in the recent developments of the policy orientation at European level, there are some slight, but significant clues of a move back towards a more 'social' concept.". Instead of moving in the pendulum way, Gualera \& Borzaga (2009) underline the need for integrative approach toward social enterprise, where rather being dichotomous and leaning either toward social or commercial dimension, is chosen way to conceptualize social enterprise along a continuum "with elements of both still to be found at the extremes"

From the perspective of legal form, the social enterprises can adopt either a non-profit or a for-profit organizational form and should not be limited to any specific legal form. This perspective results in the emergence of various hybrid organizational forms that are independent form state or other companies, they can generate profit attract grants and charity employ people and involve volunteers. Szymanska \& Jegers (2016), Young (2012), Billis (2010), Nyssens (2006), Defourny \& Pestoff (2008), Low (2006), Besley \& Ghatak (2013), Bacq \& Janssen (2011), and Artcer, Chaika \& Trukhanenko (2016) define Social Enterprises as hybrid organizations: 'mishmash' of legal forms and projects, various combination resources and institutional logics, balance between profit and social objectives, activities combining the features of social work and business, creating blended value, which includes both social and financial value, in accordance with Westall \& Chalkley (2007).

In Europe researchers distinguish three categories of social enterprises: 1) the companies whose main objective is the production of goods and services of social use or are led by a collective interest; 2) the organizations that promote local economic and social development, motivating the participation of citizens and of the government in the management of their activities; and to a greater extent, 3) the Work Integration Social Enterprises (WISE's), organizations that promote social inclusion and work (Comini et al. 2012).

States typically choose between two strategies for legal framing of social enterprise definition: some countries have created new legal forms for social enterprise by adapting or modifying existing legal forms when others entitle existing legal forms meeting certain criteria. UK, France, Greece, Italy, and Poland created new legal form for social enterprise by adapting the cooperative legal form. The United Kingdom developed a new legal form Community Interest Company, that is a limited company, which activities are being carried on for the benefit of the community, states by Urich (2013). Denmark, Belgium, Finland give 
the status of social enterprise to different traditional types of organizations if they meet the pre-defined criteria. More than 14 different legal forms are currently being used by social enterprises in Denmark. The majority of social enterprises are established as associations, foundations or companies limited by shares, according to European Commission (2015). France in 2014 provided by Kolosy (2014) a combined model, allowing traditional corporate entities and new enterprises to become social enterprises.

\subsection{Concept and definition of social enterprise in Lithuania}

\subsubsection{Historic roots and development trends}

The history of social enterprise in Lithuania is closely related to the evolution of social economy and pass through three very different historical stages: Pre-War period, Soviet Union period and Post-Soviet period. The independent development of the State's social economy system, including free market and civil society mechanism spans only twenty-five years and encompass diverse trends across the various organisational types, that make up the social enterprise universe today. Historical context left significant imprints and framed contradictory attitudes toward volunteering, non-governmental organizations or civil activism.

Until the First World War, the state was usually only an assistant for secular and catholic non-governmental organizations that provided all the basic social services. The nongovernmental organizations implemented activities with volunteers, some of organizations attracted more than 1000 of volunteers what is rare occasion in current times. During the Soviet period, tradition of active participation by NGOs in social services has ceased. During 1940-1990, provision of social services was nationalized. During the Soviet period, real volunteering was not promoted, and the desire to help each other was named as public work which was mandatory for all citizens, stated by Norvila (2007). Coercive public work contradicted the idea of volunteering and eroded volunteering basics. The negative perception of the public activists put a shadow on contemporary volunteering, NGOs and conception of social enterprises in Lithuania, based on Kurapkaitiene \& Sadauskas (2013). Since 1990 in the independent Lithuania the system of social services also started to develop with volunteering. When state independence was regained the Lithuanian non-governmental sector burst out and relied not on the past traditions, but adopted to neo-liberal conditions of free market, competition and entrepreneurship.

There can be defined two opposing directions top-down and bottom-up of social enterprise development over the last decades. Bottom up direction - refer to non-profits, mainly nongovernmental organizations moving toward entrepreneurial activities and pushing forward legislative system and support mechanisms Top-down direction is framed by the Law on social enterprises (2004), actually Work integrated social enterprises (further -WISE), which created system based on subsidies for employment and regulated entitlement to social enterprise status.

\subsubsection{Concept and legal flamengo}

There are two main legal documents defining Social Enterprise concept in Lithuania: The Law of Social Enterprises (further - the Law), confirmed by the Parliament in 2004 (Official Gazette 2004, No. IX-2251) and the Conception of Social Entrepreneurship (further - the Conception), issued in 2015 (Order 2015, No. 4-207), amended with The Recommendations (further - The Recommendations) for specification of Social Entrepreneurship criteria, issued in 2016) by the Ministry of Economy (Order 2016, No. 4-533). Both concepts are not integrated and create dichotomous situation for social enterprise ecosystem development, state support and public awareness in the future. Lithuania was among the first new EU member 
states that adopted the Law on Social Enterprises in 2004. At that moment The Ministry of Labor and Social affairs by this Law created favourable conditions for surviving of the existing enterprises of the disabled and was solely framed toward work integration of vulnerable groups. Over recent years the Law received a lot of criticism and faced significant changes. According to stakeholder interviewees ${ }^{1}$ the legal limitation of social enterprise title to WISE model has created confusion when social enterprise ecosystem started to grow and develop adopting wide variety of forms, models and aims which in 2015 initiated adoption of the Conception by the Ministry of Economy. In the legal hierarchy the Law has higher position then the Conception and formally the entitlement of Social enterprises is still implemented only following the procedures and criteria defined in the Law. However, social enterprise criteria, defined by European Commission Social Business initiative, 2011 and the Conception, 2015 are almost not represented in the WISE model in Lithuania. Social enterprises, entitled by the Law are not required to reinvest their profit for the social cause, there is no obligation to address social objectives over commercial objectives, to remunerate fairly the employees or to engage representatives of the main stakeholders or the members of the target groups in the governance of the social enterprise as recommended by European Commission and EMES. Such discrepancy creates broad discussion, if these de jure entitled "social enterprises" really fit in the term and title of social enterprise, if they distort main principles of social entrepreneurship. The Conception approved by The Ministry of economy in 2015 was developed on the basis of The Social Business Initiative of European Commission, 2011 and good practices of European countries, having long history of social entrepreneurship, like UK, France, Italy. The conception was amended in 2016 adding the Social enterprise criteria, which moved initially broad social enterprise pendulum toward the neo-liberal market dimension and draw clear distinction between non-profits and profit oriented companies by placing relatively high 50\% threshold for incomes to be generated from free market trade, obligation to have only employees, but not volunteers and requirement for profit reinvestment to social aim not less than 50\%. Referring to the Conception, in 2017 the Ministry of Agriculture passed the order "On guidelines for implementation of social business within the LEADER program for rural development 2014-2020" (further in text used - The Guidelines) - the first large scale financing program for start-up development of social enterprises. The Conception and the Guidelines also explained and defined detailed criteria for social enterprise model, such as profit reinvestment, social impact measurement, inclusive management and other. The Guidelines made some adjustments and balanced social enterprise pendulum toward social impact dimension, still holding quite high commercial incomes requirement. It additionally requires to measure social impact, include stakeholders into management and reinvest not less than $80 \%$ of surplus to social impact. Both the Conception and the Guidelines indirectly exclude de jure social enterprises as following their criteria in order, to refer to social enterprise model is not enough only to employ vulnerable target groups, other dimensions - such as social aim priority, surplus reinvestment, inclusive government are obligatory. In Lithuanian legal framework currently are operating two very different types of social enterprises. Both represent separation focused approach toward social enterprise definition, both drawing and analysing own universe of social enterprises. Such dichotomy created situation, where some public reports count several hundreds of social enterprises, if refer to Social enterprises defined by the Law and other - state, that there is no Social Enterprise in Lithuania, if relying on the Conception's criteria and the Guidelines,

\footnotetext{
${ }^{1}$ Note: Authors implemented stakeholders' interviews, 39 reposndents, representing academicians, policy makers and social enterprise practitioners were interviewed in 2018, March.
} 
stated by Feasibility Study on social enterprise development in Lithuania (2017). Confusion creates conflict around "who is real social enterprise", stagnate any policy making strategies, bring ambiguity around donors and financial investors and grow distrust of society. The presented case illustrates possibility and lesson to learn, how theoretical adoption of social enterprise conception to legislative system, blind to local emerging ecosystem and historical, cultural context can lead toward greater uncertainty. The case of Lithuania also calls for broader discussion if social enterprise development need exclusive legal framing and topdown entitlement and regulation systems or this is more movement-like self-regulated polycentric system managed by members' practitioners through self-organization principles, argued by Ostrom (2008). Long-term studies, analysing evolutionary stages of social enterprise development through cultures could help to divert guidelines for strategic development and acceleration of social enterprises ecosystem for countries and regions.

\section{Results}

\subsection{Social enterprise universe in Lithuania - between polarities}

Organizing universe of social enterprises in Lithuania we define two areas: social enterprises and the grey area as presented in Fig. 1. Social enterprise domain encounter actors, that satisfy any of two legal definitions of social enterprises in Lithuania and can be identified by public sources or researches. NGOs, generating incomes, meet social enterprise criteria, adopted in the Conception (2015) and Social enterprises are entitled by the Law on social enterprise (2004). NGOs, generating incomes are identified using research data and official information of Statistics Lithuania. Social enterprises are publicly listed at the Lithuanian labour exchange. The actors within the grey domain of social enterprise universe include organizations, that have some representations of social enterprise dimensions, but either don't integrate social entrepreneurship on permanent mode (Socially responsible enterprises and Philanthropic NGOs), or don't identify itself as social enterprise (cooperatives) or are not independent (state controlled non-profits). This article will analyse and identify social enterprise domain: NGO generating market incomes and Social enterprises, representing dichotomy of social enterprise universe development trends - top-down direction, represented by social enterprises, entitled by the Law, 2004 and NGOs - representing bottom-up rise.

\section{Figure 1: Social enterprise universe in Lithuania}

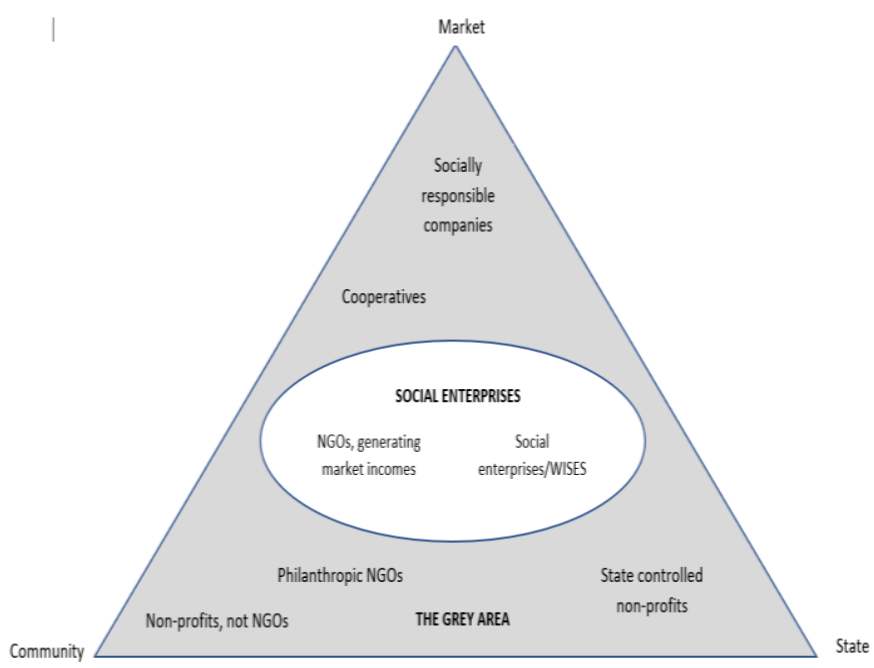

Source: author's compilation 


\subsection{Social enterprises - e.g. work integrated social enterprises}

In Lithuania legal recognition of Social Enterprise term came in 2004 when the Law on Social Enterprises (Official Gazette 2004, No. 96-3519) was passed by Ministry of social security and labor as part of actions for implementation of employment strategy by redirecting to social enterprises part of public services. Together with entering the EU, Lithuania got access to structural funds assistance and needed to harmonize national legal framework with the EU's legislation. Opportunities to get the ESF assistance to social enterprises through public subsidies and the possibility for individuals to establish Social Enterprise under the Law on social enterprises created favorable conditions for surviving of the existing organizations of the disabled and gave impetus to establishment of new Social Enterprises. ${ }^{2}$

However, current requirements to social enterprises define $d$ by the Law (2004) narrow the concept of social enterprise to single purpose - work integration of vulnerable groups and therefore represent work integration social enterprise (WISEs) model. This model partially reflect the EU proposed social enterprise conception. Under the existing Law social enterprises are not required to reinvest their profit for the social cause, there is no obligation to address social objectives over commercial objectives, to remunerate fairly the employees or to engage representatives of the main stakeholders or the members of the target groups in the governance of the social enterprise. At the beginning of 2018 there were 187 social enterprises and 63 of them - were social enterprises of the disabled (not less than $50 \%$ of employees are persons with disabilities), according to Lithuania Labour Exchange (2018). 91 $\%$ of social enterprises/WISEs constitute commercial companies: joint-stock companies, private limited liability companies, individual enterprises and 9\% - public enterprises. Analysis of Social enterprise data provide by Lithuanian Labour exchange Social enterprises are mostly engaged in low skill jobs of them the most popular are cleaning, construction, food production and catering, sewing, knitting, production of jewellery, toys, see Fig 2. Some social enterprises are also involved in consulting, bookkeeping, archives, photography, translations. Social enterprises of disables mostly are operating in cleaning and consulting and bookkeeping and production areas.

Figure 2: Social enterprises' business activities

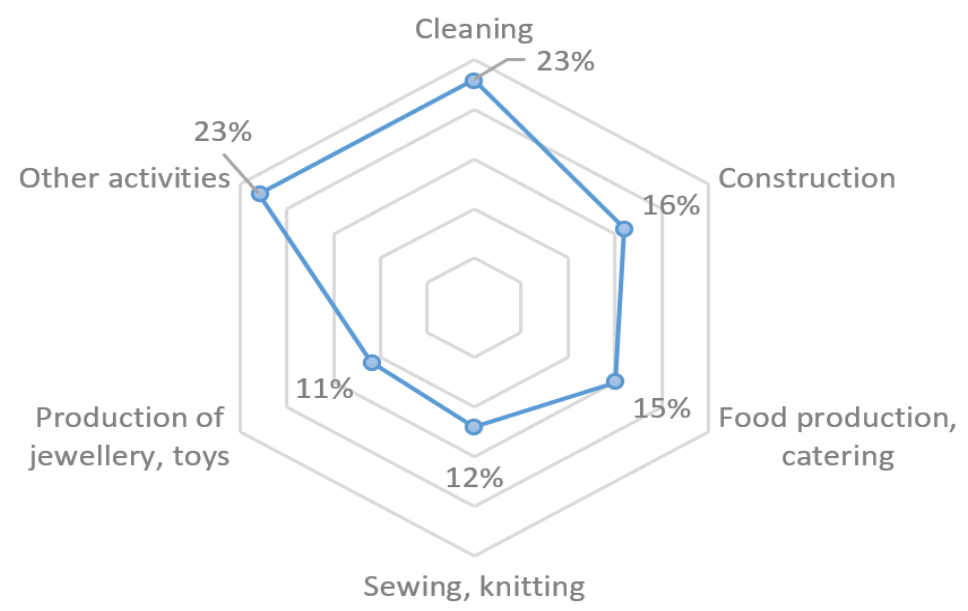

Source: author's compilation according to Lithuanian Labour Exchange, 2018 March

\footnotetext{
${ }^{2}$ Note: Until 2004 there were about 20 organisations of the disabled, which could be established only by public institutions, received funding only from state budget depending on organisation's energy costs and on the total amount of social security contributions paid.
} 
In addition to state support schemes in the form of subsidies (state aid), social enterprises have a right to receive public support under other legal acts, including those establishing support of small and medium sized enterprises (SMEs), as well as the social programs financed from the State budget and monetary funds. Various types of state aid provided by legislative system of Lithuania to social enterprises are summarized in the Fig.3.

Figure 3: Types of state aid provided to Social Enterprises by legislative system of Lithuania

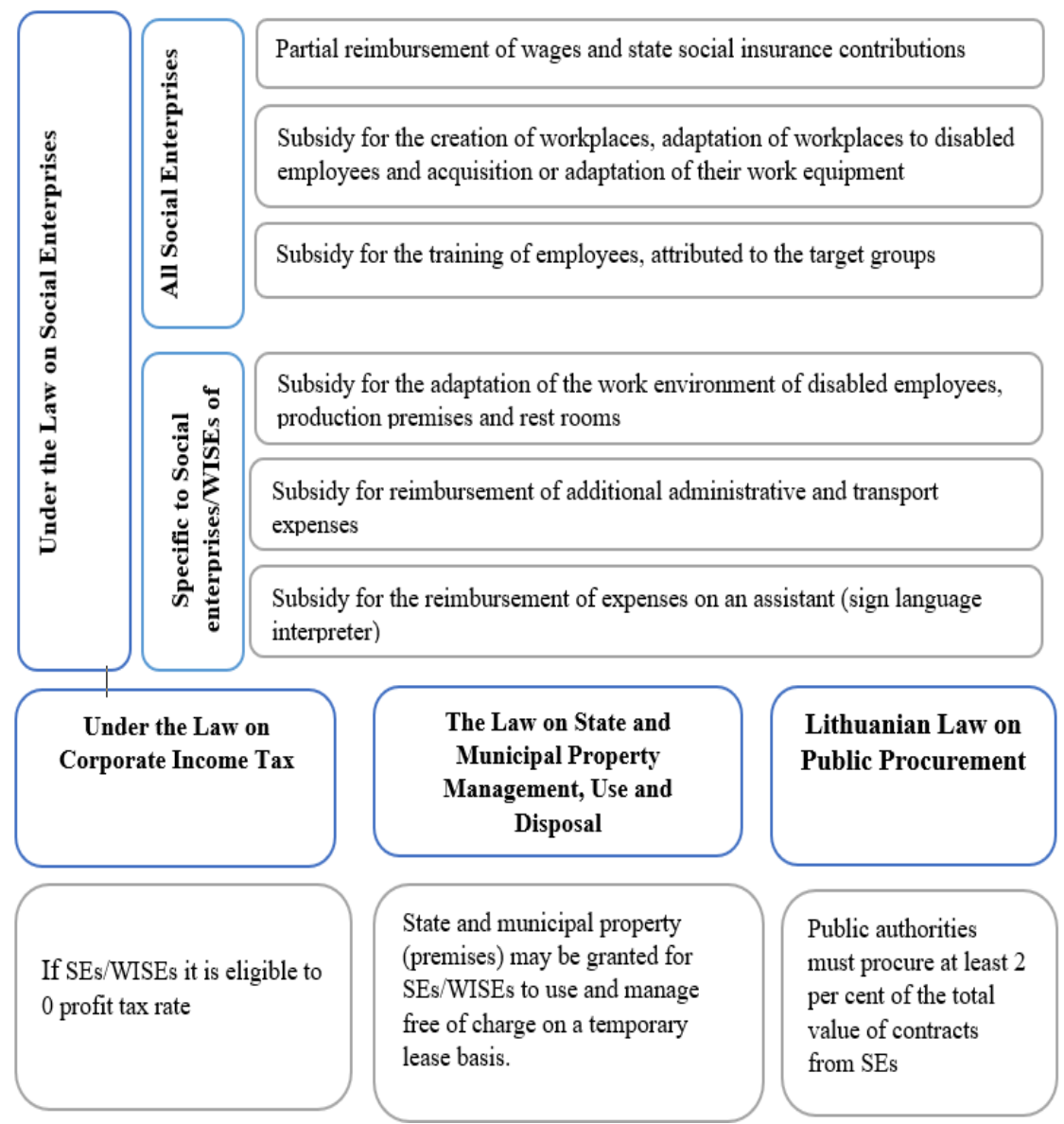

Source: author's compilation according to Ministry of Social Security and Labour and Lithuanian Labour Exchange

Since 2004 the number of SEs and number of employees under subsidies grew 14 times, the amount of state support to SEs - increased 19.5 times; average subsidy per SEs as well average subsidy per employee increased 1.4 times. At the end of 2017 there were 186 social enterprises which employed 9356 persons by the state subsidies, of them 7941 (85\%) are persons with disabilities and EUR 23.4 million were spent for subsidies to social enterprises in 2017 January-November (Lithuanian Labour Exchange, 2018). The state financial burden to preserve social enterprises is growing especially with EU structural fund termination. Therefore, broad public and political discussion are occurring concerning the systemic transformation of social enterprise financing system.

Research by Okuneviciute Neverauskiene \& Moskvina (2011) showed that first social enterprises established in 2004-2005 were mostly focused on the employment of the disabled by subsidies, encouragement to return to work and their social integration. Currently these social enterprises operate with a rising focus on economic and not social objectives (similarly as other business companies), however, with much better access to public funding and tax exemptions than any other business enterprises or social enterprises. 
Current case of Lithuania shows than in the long run narrow definition of scope and operational model of social enterprise (e.g. employment) in line with top-down regulation linked to permanent state financing (e.g subsidies) confirmed by the law, creates contradictory impact. On the one hand the positive outcome comes from legitimization of the Social Enterprise concept on the system level, what creates conceptual and legislative background for development of know-how, social innovations, research, scientific and education context of Social Economy and social entrepreneurship. On the other hand, the Lithuanian model had created discrimination toward other forms of social enterprises and according to some analytics and sociological pools even deformed key principle of social entrepreneurship focus to solve social problem, according to Okuneviciute Neverauskiene \& Moskvina (2011), and Map of social enterprises (2014).

Special investigation service of the Republic of Lithuania in "The conclusion of the anticorruption assessment regarding the legal regulation of the activities of social enterprises", 2018 determined that majority of the state financial support from all the planned aid measures to social enterprises were targeted to create value not to the target groups but to the social enterprises themselves. Since the 2010 debates were going for and against existing definition and regulation of Social Enterprises, mostly fostered by the interest of different State actors, such as Ministry of Economy, Ministry of Agriculture, Ministry of Internal Affairs, which through various donor programs stepped into the field of Social Entrepreneurship, that historically used to be related only to issues of Social Affairs. New actors set new aims and priorities for Social Entrepreneurship thus supporting development of diverse ecosystem of Social Enterprises in Lithuania. Recent 5-7 years Lithuania faced boom of public narratives around social responsibility and sustainability to create arena for wide range of stateindependent initiatives and multi-stakeholders' dialogues around Social Economy and Social Entrepreneurship. In 2015 the Government approved new Conception of Social Entrepreneurship, that instead of creating broader balanced visions pushed pendulum toward Economic factors of Social Entrepreneurship.

Lithuania in the upcoming decade plans to overcome systemic evolutionary challenge deinstitutionalisation of public services. That is a highly complex transformation, it is a mental paradigm shift of trust, that public value can be generated by non-government actors; that expertise, social impact and intelligence to solve state problems can be outside the state establishments, that profit seeking can generate social cohesion and wellbeing of the society through broader variety of models then state controlled redistribution of taxes. Social Entrepreneurship is a great example of such paradigm shift and therefore shall be appreciated with importance and elaborated in every country uniquely allowing the original ecosystem to develop its own way instead of embedding good practices of other countries. Conceptions, regulations and definitions of social entrepreneurship shall work as arena to discuss more inclusive, collaborative, flexible, and innovative cross-sectoral forms of public, private and collective economies.

\subsection{NGOs generating market incomes}

NGO status in Lithuania is defined by the Law on the Development of Non-Governmental Organizations (2013). Non-governmental organization is appointed a public legal entity, independent of the state or municipal institutions and bodies, acting on behalf of the public or of a group, the purpose of which is not the pursuit of profit or political power or solely of religious aims. In Lithunia NGO universe consitute of 3 legal forms: public enterprises, associations and foundations. In January 2018 The Statistics of Lithuania counted 11261 active legal entities, entitled to NGOs: associations - 7445, public enterprises - 3514 (4193 - 
registered legal entities with legal form of public enterprise, extracting 679 - public enterprises, that managed by the state institutions), foundations - 302 as presented in the Fig. 4 associations encounter the largest part of NGOs in Lithuania.

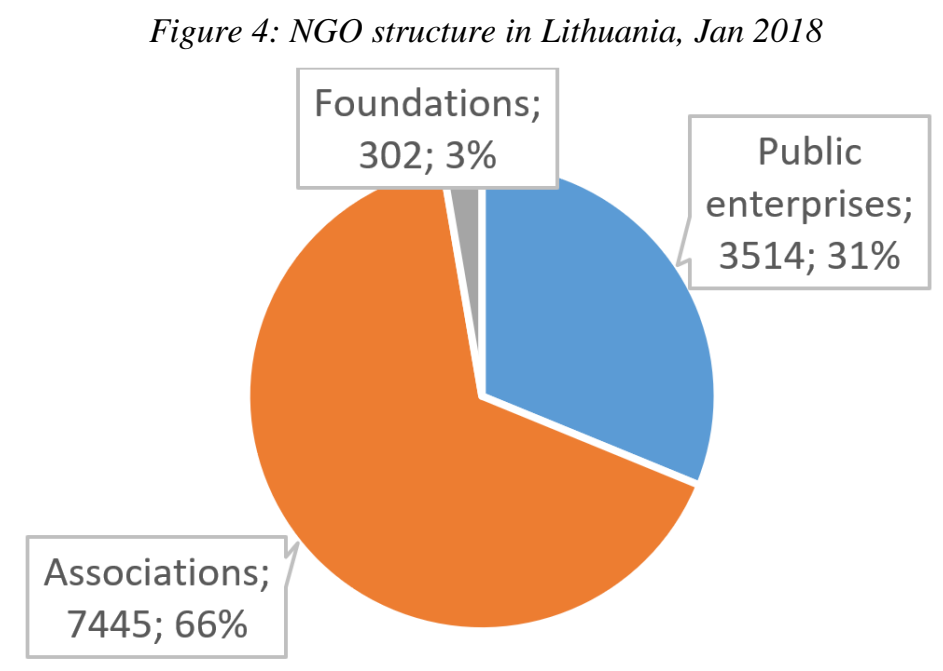

Source: author's compilation according to Statistics of Lithuania, 2018

The growth of NGOs was significantly accelerated by EU structural funds and other international donors and was growing exponentially till 2015, when requirement to provide financial reports to state institutions came into force and non-active NGOs closed or suspended activities. As presented in Fig. 5, in 2015 number of associations, which mostly were local communities, decreased in $64 \%$, public enterprises and foundations continued growing. The current number is steadily increasing and represent active NGOs.

Financial structure of NGO is comprised of: membership fee, $2 \%$ support from income tax paid by individuals, municipal budget funds, state budget funds, international funding programs, private funding, incomes from economic activities. Research of Non-governmental sector, Eurointegracijos projektai development (2014) implemented using interviews with wide number of NGOs show, that $67 \%$ do not carry out activities generating income outside the grant projects, and 33\% claim carrying out such activities, $23 \%$ of NGO representatives say that economic activities are permanent and provide constant income.

Figure: 5 Dynamic of NGO for 2010-2018*

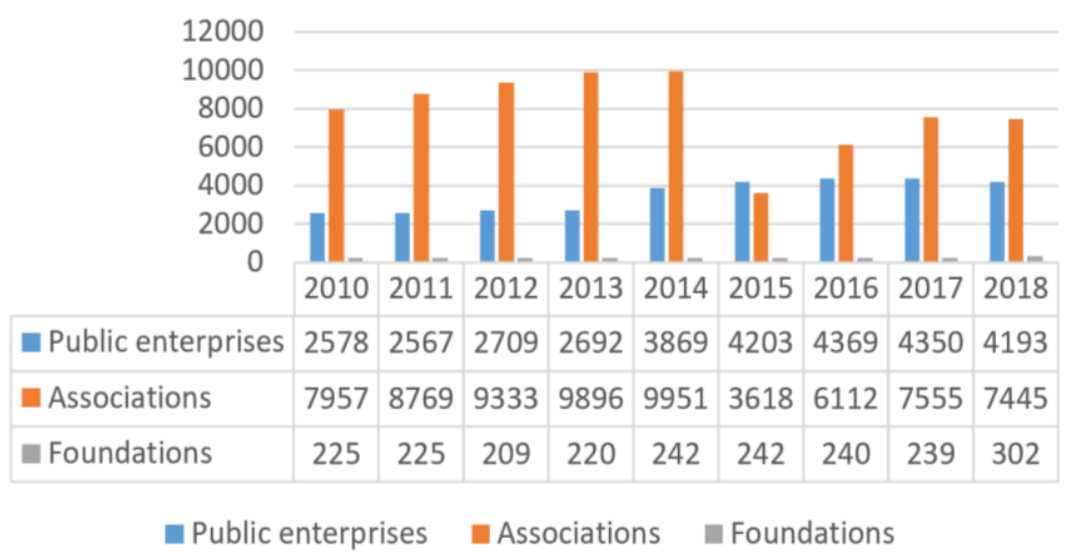

Source: author's compilation according to Statistics of Lithuania, 2018

* State or municipality governed public enterprises (not entitled to NGO) are not extracted from the list due to lack of data 
Statistics Lithuania under authors request in 2018 March provided analysis of public enterprise legal entities (one form of NGOs) financial data and divided them into four groups by percent of incomes generated from market in the total income structure: 1469 (35\%) of all public enterprises in 2016 generated more than $50 \%$ of incomes from the market, more than $25 \%$ incomes from market generated $1695(40 \%)$ and $603(14 \%)$ generated less than $10 \%$, of all active public enterprises. The trend is that number of public enterprises who provide financial reporting and generate market incomes is growing. Following the Conception of social enterprise (2015) only such enterprises that generate not less than $50 \%$ of income from the market are eligible to social enterprise status.

There is no official data available on other forms of NGOs - associations and foundations incomes, and in order to come up with approximate number of social enterprises, eligible by the Conception (2015) we make expert calculation based the number presented in the " Research of Non-governmental sector development" (Eurointegracijos projektai, 2014), stating, that $\mathbf{2 3 \%}$, of NGOs carry out permanent activities generating incomes outside the grant projects, thus around $\mathbf{2 5 9 0}$ of NGO could be treated as meeting social and enterprise dimensions for social enterprises.

Interviews of the NGOs representatives (2014) showed, that economic activities, generating incomes from market trade, most often are education and training services, social services, sports, cultural, health and environmental activities, detailed picture presented in Fig. 6. Analysis of public enterprises by Statistics Lithuania also show, that education and sports are the most popular activities.

Stakeholders interviews, implemented by authors in 2018, revealed, that NGOs do not see significant legal or motivational barriers to start income generating activities. "There are no barriers to run social enterprises in Lithuania. Sure, there is a need for preferences and discounts, but that will create uneven conditions for competition and split up society or will attract to social enterprises businessmen, that are not interested to solve social problems, but to gain from preferences.", - said one of the respondents of the stakeholders' survey.

Figure 6: NGO activities generating market incomes

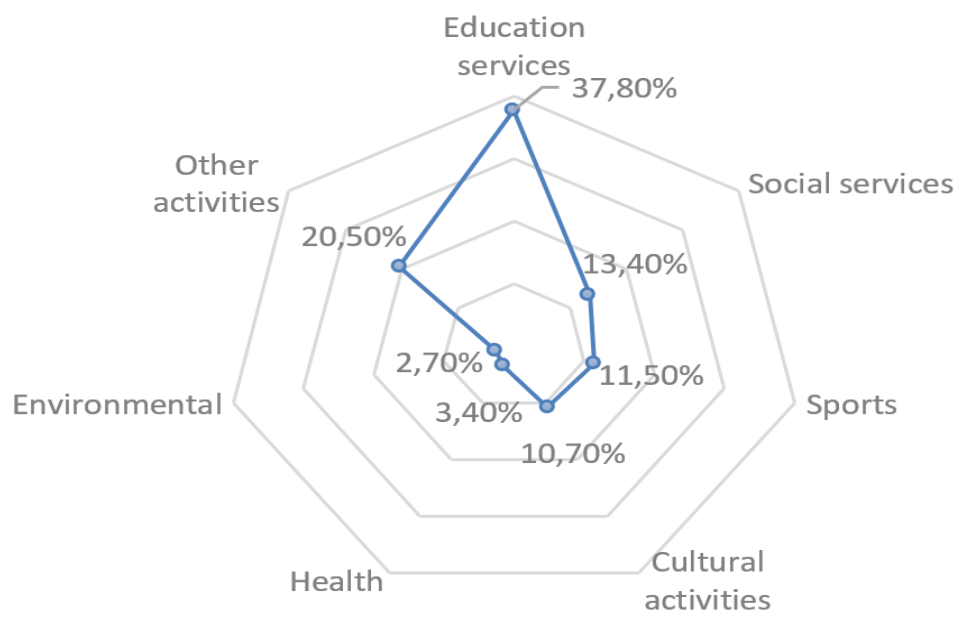

Source: author's compilation according to Research of Non-governmental sector development (2014), Eurointegracijos projektai

The most commonly mentioned reasons why NGOs do not carry out economic activities in Lithuania are lack of start-up investments, lack of competences and infrastructure; lack of support and collaboration from state institutions and municipalities, fear of competition.

1. NGOs does not have initial financing to start business $(47,3 \%)$; 
2. Does not have the necessary knowledge, skills and infrastructure $(42,4 \%)$;

3. There is a lack of understanding of the authorities/state and municipal administrations about the procurement procedures of purchasing services from NGOs $(40,2 \%)$;

4. Municipalities are not inclined to change public services providers and to purchase more services from NGOs $(31,8)$;

5. difficult to compete with business companies providing similar services $(31,7 \%)$

6. difficult to compete with state institutions/companies providing similar services $(30,6 \%)$

7. NGO employees usually are fully occupied by implementing projects $(23,1 \%)$

8. NGOs don't know they can run economic activities $(21,7 \%)$

9. Lack of business ideas (19\%)

10. Board or shareholders of organization do not support execution of economic activities $(3,9 \%)$

11. Other $(11,1 \%)$

Involvement of social enterprises in the provision of public services to municipalities is one of the publicly discussed issues in Lithuania. Interviewed practitioners see entrepreneurial opportunities for social enterprises in provision of public services, if municipalities and state institutions would be ready to collaborate and open the public service market to independent providers. In the context of deinstitutionalization of public services, there is a growing demand for social enterprises to develop capacities and engage. By the order of the Minister of Social Security and Labour of the Republic of Lithuania of 16 November 2012 Strategic guidelines for deinstitutionalization of the social care homes of disabled children deprived of parental care and adult disabled persons and the order of 14 February 2014 Transition from institutional care to community-based services for the disabled and children deprived of parental care 2014-2020 action plan, there shall be created system of "a comprehensive range of services that enable every child, person with disabilities or their families (guardians) to receive individual services according to their needs and necessary assistance in the community, and every child deprived of parental care to grow in a safe environment in his biological or foster family."

Summarizing can be said that NGOs historically and currently comprise significant role in social enterprise universe development. The entrepreneurial capacities of NGOs are undervalued. The trends show growing number of non-profits moving toward sustainable entrepreneurial engagement and new social enterprises mostly open using NGO legal forms. With structural changes and stronger decentralization of public service provision as well with acceleration, incubation of bottom-up initiatives, NGOs could create a significant growth potential for social enterprises universe in Lithuania.

\section{Discussion}

Social enterprise ecosystem in Lithuania is overcoming through transformational passage where meet not only two social enterprise definitions, but two systemic paradigms of management: top-down versus bottom-up, two paradigms of welfare development: economy and social versus social-economy. The leverage point in such situation is through overcoming polarities and pendulum dynamic toward more integrated and complex solution, that could balance between self-regulation of actors and acceleration through intervention by the state or other donors. Indeed, it is obvious that social enterprise ecosystem is much bigger issue than definition of certain entrepreneurial form and they call for development of new public management, financing and collaboration forms, in order not to limit, but to support naturally 
emerging social innovations, according to DeVries (2015). Important and often omitted in the public discussions accent by European Commission, that there is no single legal form for social enterprises. "Many operate in the form of social cooperatives, some are registered as private companies limited by guarantee, some are mutual, and a lot of them are no-profitdistributing organisations like provident societies, associations, voluntary organisations, charities or foundations", provided by European Commission (2017). The Social Business Initiative of European Commission, define social enterprise as an enterprise that combines societal goals (social, environmental or community objectives) with entrepreneurial spirit. European Commission identify 4 elements that shall be expressed in the business model of the enterprise to apply for Social Enterprise identity: (i) social impact, (ii) economic sustainability and surplus reinvestment, (iii) transparency and democratic management, (iv) innovation. EMES $^{3}$ on the basement of $15 \mathrm{EU}$ countries research has offered set of social and economic criteria, applied for the Social Enterprise business model. These criteria, mentioned in the Fig. 7 give broad scope for various forms of social enterprises to appear and at the same time holds a backbone logic behind social entrepreneurship concept.

Figure 7: Social and economic criteria applied to Social Enterprises

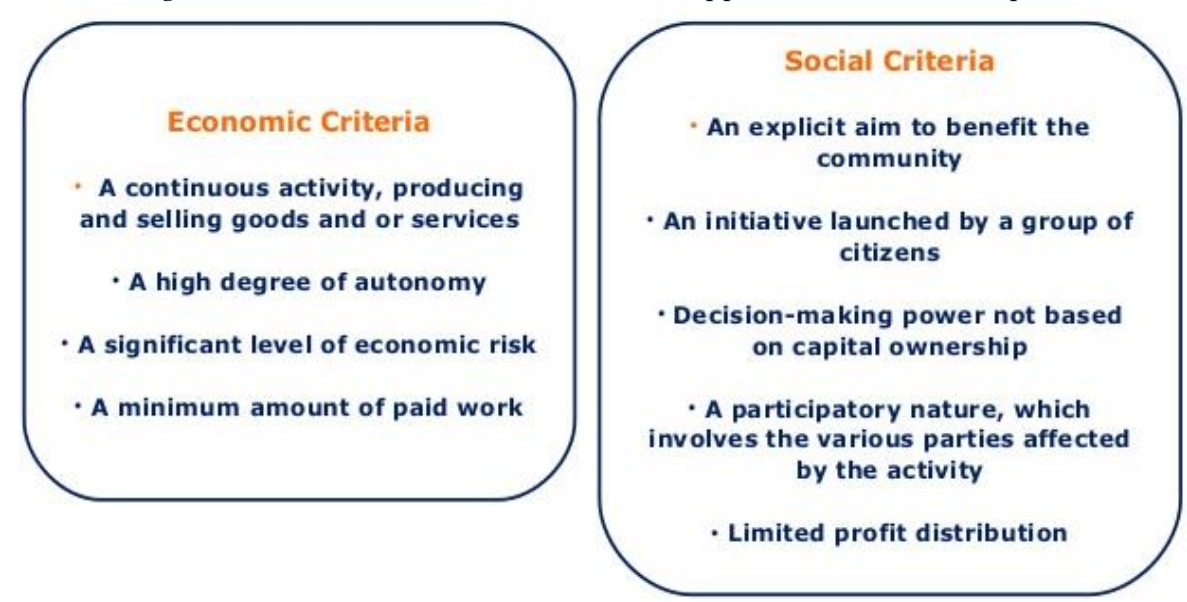

Source: author's compilation according to EMES (2011)

Following European Commission and EMES approach social enterprise does not need legal definition of the form and is more about business model and management principles applied to any kind of entrepreneurship. Any conception of social enterprise on national level shall appreciate this complexity and focus on definition of the criteria and principles in the continuum, respecting the existing representation of elements in the history and present context of the country.

\section{Conclusion}

The case of Lithuania show that social enterprise models emerge in various forms and sectors, therefore it is important for country to develop inclusive and broad approach toward the conception of social entrepreneurship, responding to actual social enterprise ecosystem and variety actors.

${ }^{3}$ Note: EMES is a research network of established university research centres and individual researchers whose goal has been so far to gradually build up a European corpus of theoretical and empirical knowledge, pluralistic in disciplines and methodologies, around our "SE" concepts: social enterprise, social entrepreneurship, social economy and solidarity economy. 
Adoption of theoretical frameworks based on the good practice experience of historically different countries on one hand draw direction and bridges local context toward European paradigm, on the other hand may distort and misrepresent the unique universe, historically formed in the country.

Research and understanding of complexity of social enterprise ecosystem, where systems within system evolved through cultures and time, could help to define basic kernel of social enterprise universe - general broad principles, that later could be adopted and translated into specific criteria representing a unique national pictures. One of the examples to such core principles for social enterprises was presented by Defourny (2012) "triangle", that "highlights three action logics and resources on which these actors rely to develop their activities: market principle facilitates the supply and demand for goods and services; redistribution is the principle when part of the production is handed over to State; reciprocity principle means exchanges based on the gift and regulated by social norm.

Policy makers engaged in framing of social enterprise definition shall pay attention to local and global evolutionary discourse, shall appreciate cross sectoral nature of social enterprises and their special place in the overall economy. Defourny (2012), Phills, Deiglmeier \& Miller (2008), Kania \& Kramer (2013) underline, that social entrepreneurship as main catalyst for social innovations go beyond conventional "bi-polar" representations of the economic landscape, which only stress the central place of the market and the regulatory role of the state. The non-profit sector can no longer be viewed as separate to the business or state sector, instead, social enterprise models appear as intermediate actors. This view emphasizes the need for synergetic mixes of resources, cross-sectoral policies making and support means to social enterprise organizations, rather than clear-cut frontiers and divisions between sectors.

\section{References}

Artcer, T., Chaika, Y. \& Trukhanenko, A. (2016). Mentoring as an Essential Element of Social Entrepreneurship. WELLSO 2016- III International Scientific Symposium on Lifelong Wellbeing in the World.

Austrian Institute for SME Research (2007). Study on Practices and Policies in the Social. Enterprise Sector in Europe. Finland. Austrian Institute for SME Research and. TSE Entre, Turku School of Economics.

Bassi, A., Ecchia, G. \& Guerra, A. (2016). Social Innovation Policies with the involvement of Social Economy organizations: Survey Evidence from European Countries. Bruxelles: European Commission. Innovative Social Investment: Strengthening communities in Europe (InnoSI), No. Deliverable 3.2, InnoSI Working Papers, No. WP3.

Besley, T. \& Ghatak, M. (2013). Profit with Purpose? A Theory of Social Enterprise with Experimental Evidence. Economic Organisation and Public Policy Discussion Papers.

Billis, D. (2010). Hybrid Organisations and the Third Sector. Challenges for Practice, Theory and Policy. New York, USA: Palgrave-MacMillan.

Borzaga, C. \& Defourny. J. (2001). The Emergence of Social Enterprise. London and New York: Routledge.

Cels, S., de Jong, J. \& F. Nauta (2012). Agents of Change: Strategy and Tactics for Social Innovation. Washington, USA: Brookings Institute Press.

Communication from the Commission to the European Parliament, the Council, the European Economic and Social Committee and the Committee of the Regions (2011). Social Business Initiative (2011). Creating a Favourable Climate for Social Enterprises, Key Stakeholders in the Social Economy and Innovation. Brussels, Belgium.

Defourny, J. (2004). Social Enterprises in an Enlarged Europe. Proceedings of the 2nd European Social Economy Conference. Prague, Czech Republic: 1-21.

Defourny, J., Hulgard, L. \& Pestoff, V. (2014). Social Enterprise and the Third Sector. Changing European Landscapes in a Comparative Perspective. London and New York: Routledge.

De Vries, H., Bekkers, V. \& Tummers, L. (2015). Innovation in the Public Sector: A Systematic Review and Future Research Agenda. Public Administration, 94(1), 146-166. 
Ekonomines konsultacijos ir tyrimai (2017). Survey on Non-governmental organization opportunities to provide public services and citizens involvement into volunteer activities.

European Commission (2015). Directorate-General for Employment, Social Affairs and Inclusion (2015). A Map of Social Enterprises and their Eco - Systems in Europe. Luxembourg: Publications Office of the European Union.

Feasibility study on Social Enterprise Development in Lithuania (2017). Lithuanian Innovation Center \& Association Knowledge economy forum.

Gualera, G. \& Borzaga, C. (2009). Social Enterprise: An International Overview of its Conceptual Evolution and Legal Implementation. Social Enterprise Journal, 5(3), 210-228.

Kolosy, K. (2014). The Law on Social and Solidarity Economy. In European Commission. Growth. Social Innovation Europe.

Kurapkaitiene, N. \& Sadauskas, J. (2013). Volunteership in Social Work: Correlations and Strains. Jaunuju Mokslininku Darbai, 2 (40), 83-88.

Nyssens, M. (2006). Social Enterprise - at the Crossroads of Market. Public Policy and Civil Society. London, Great Britain: Routledge.

Norvila, J. (2007). Volunteership Lithuanian Way. Collection of Articles about Volunteering, Kaunas, Lithuania: A.C. Patria.

Map of social enterprises and their eco-systems in Europe (2014). Country Report: Lithuania.

Kania, J. \& Kramer, M. (2013). Embracing Emergence: How Collective Impact Address Complexity. Stanfords Social Innovations Review, 1-8. Available at: 〈https://ssir.org/articles/entry/collective_impact>.

O’Byrne, D., Lean, J., Moizer, J., Walsh, P., Dell'Aquila, E. \& Friedrich, R. (2015). Social Enterprise in the European Union: A Review of Policy. Social \& Public Police Review, 9(1), 15-16.

Okuneviciute Neverauskienė, L. \& Moskvina, J. (2011). Social Enterprises: Aspect of Social Economy Development. Philosophy \& Sociology, 22(4), 384-393.

Order of the Minister of Social Security and Labour of the Republic of Lithuania (2012). Strategic Guidelines for Deinstitutionalization of the Social Care Homes and Disabled Children Deprived of Parental Care and Adult Disabled Persons, 16 November 2012, No A1-517.

Order of the Ministry of Social Security and Labour of the Republic of Lithuania (2014). Transition from Institutional Care to Community - Based Services for Disabled and Children Deprived of Parental Care 2014-2020 Year Action Plan, 14 February 2014, No. A1-83.

Order of Minister of Agriculture (2017). Guidelines for Implementation of Social Business within the Program Means for Development of Rural Areas for 2014-2020, 2017 November 9, No 3D-720, ID 2017-17669.

Ostrom, E (2008). Polycentric Systems as One Approach for Solving Collective Action Problems, 1-22. Available at: 〈https://ssrn.com/abstract=1304697〉.

Phills, Jr. J.A., Deiglmeier, K. \& Miller, T.D. (2008). Rediscovering Social Innovation. Stanfords Social Innovations Review, 6(4), 34-43.

Presentation by the Ministry of Social Security and Labour of the Republic of Lithuania (2014). Transition from institutional care to the family and community based social 2014-2020. Available at: <https://socmin.lrv.lt/uploads/socmin/documents/files/pdf/9817_pertvarkos-pristatymas-ek-anglu.pdf>

Special Investigation Service of the Republic of Lithuania (2018). The Conclusion of the Anti-Corruption Assessment Regarding the Legal Regulation of the Activities of Social Enterprises, No. S-2017-10543.

Staicu, D. (2017). Policy Framework and Legal Forms of Social Enterprise in Central and Eastern Europe. Proceedings of the International Conference on Business Excellence, 11(1), 875-883.

The Republic of Lithuania (2013). Law on the Development of Non-Governmental Organizations, December 19, No. XII-717.

The Republic of Lithuania (2016). The Recommendations for Specification of Social Entrepreneurship Criteria. The Ministry of Economy on 29 August 2016, Order No. 4-533.

The Republic of Lithuania (2015). Concept of the Social Entrepreneurship. Adopted by the order of the Minister of Economy of the Republic of Lithuania, TAR 2015-04-03, No. 5148

Urich, T.F. (2013). Business Organizations in the 21st Century: A Look at New Legal Forms for Business that Enhance Social Enterprise. Southern Law Journal, 23(2), 329-343.

Young, D.R. (2012). The State of Theory and Research on Social Enterprises. Social Enterprises: An Organisational Perspective, 19-46.

Westall, A. \& Chalkley, D. (2007). Social Enterprise Futures. London: The Smith Institute. 